\title{
Analysis of quality of Alms service to satisfaction and compliance paying alms in academic envi-
} ronment

\author{
Ira Murweni ${ }^{a b *}$, Nanang Fattah ${ }^{a}$, Kusnendi ${ }^{a}$ and Mokh. Adib Sultan ${ }^{a}$
}

${ }^{a}$ Graduate School, Universitas Pendidikan Indonesia, Bandung, West Java - Indonesia

${ }^{b}$ Politeknik Piksi Ganesha Bandung, West Java - Indonesia

\section{H R O N I C L E}

\section{Article history:}

Received: May 30, 2020

Received in revised format:

May 302020

Accepted: June 21, 2020

Available online:

June 23, 2020

Keywords:

Academic environment

Good corporate government

Service quality

Satisfaction

Religious obligation

\section{A B S T R A C T}

The purpose of this study is to determine the impact of applying the principles of Good Corporate Government on the quality of alms services and measure the effect of these service standards on the compliance and satisfaction of alms services for alms payer (muzzaki). The method used in this research is Structural Equation Modeling (SEM) model measurement test with simple random sampling technique and the data is processed using AMOS 22 software. The benefit of this research is to find out whether the application of the principles of Good Corporate Government is able to influence compliance and muzzaki satisfaction in paying their alms obligations so that alms management organizations can find out what factors need to be considered in optimizing their participation in fulfilling their alms obligations with full awareness.

(C) 2020 by the authors; licensee Growing Science, Canada

\section{Introduction}

All the world's major religions contain several elements of alms, and faith plays a key role in funding and sending humanitarian responses throughout the world. Although it cannot say how much religiously motivated donations occur globally each year, it is clear that faith-based organizations mobilize and channel a large portion of humanitarian assistance globally and are actively involved in its delivery. In 2013, faith-based organizations received and sent between US \$ 420 million and US \$ 434 million (15-16\%) of all international humanitarian assistance distributed through non-governmental organizations (NGOs). Islamic countries and countries with large Muslim populations are also very significant humanitarian actors, both as donors and recipients. Between 2011 and 2013, international humanitarian assistance from the government in the Organization of Islamic Cooperation (OIC) grew from US \$ 599 million to more than US \$ 2.2 billion, representing growth in the total portion of international humanitarian assistance from the government from $4 \%$ to $14 \%$. At the same time, it is estimated that $75 \%$ of people living in the ten largest recipient countries in 2013 were Muslim. This is based on the Development Initiatives analysis based on UN OCHA FTS data. Alms, a compulsory Muslim practice of giving $2.5 \%$ of one's accumulated wealth for charitable purposes each year, is one of the main tools of Islamic social financing. The five pillars of Islam are shahadah (declaration of Faith), salah (prayer), alms, fasting in the month of ramadan, and hajj (pilgrimage to Mecca)). This is explicitly intended to reduce inequality and is widely used in Muslim countries to fund domestic development and poverty reduction efforts. There are clear parallels to be drawn between the eight categories of individual recipients of Alms who fulfill the requirements listed in the Qur'an and those who need humanitarian assistance. Alms can be paid in different ways to different institutions, both government and non-government, often depending on the country where a Muslim lives or on their Islamic sect. No reliable data are currently available to show exactly how much alms is paid by every Muslim around the world, or how it is spent globally (Saunders, 2013). But based on data collected from Indonesia, Malaysia, Qatar, Saudi Arabia and Yemen, which * Corresponding author.

E-mail address: iramurweni.upibdg@gmail.com (I. Murweni) 
constitutes $17 \%$ of the estimated Muslim population in the world, showing that in these countries alone at least US \$ 5.7 billion is currently collected in alms each year. This figure compiled using Pew Research Center data on Muslim demographics (www.pewforum.org/2011/01/27/table-muslimpopulation-by-country/). Alms is estimated to have the potential to provide an equivalent of $1.59 \%$ and $3.82 \%$ of GDP in Indonesia or between US \$ 13.8 billion and US $\$ 33.2$ billion per year (Baznas, 2014; Beik, 2014; Vicente-Ramos et al., 2020). The two main alms collection agencies in Indonesia spend an average of 34\% of their collective income on humanitarian assistance despite the constraints on the lack of available data, but it seems that all or a large part of this alms fund is spent domestically. If by using the same proportional details, then Alms could potentially provide funding between US \$ 4.7 billion and US \$ 11.3 billion for humanitarian assistance in Indonesia each year. Indonesia has a high potential for alms funds to overcome poverty (Johari, Mohd Ali, Ab Aziz, \& Ahmad, 2014). Based on research conducted by Firdaus et.al (2012), the potential for alms in Indonesia reaches Rp 217 trillion. This is equal to $11.45 \%$ of Indonesia's national income in 2018. However, the 2017 National Alms Agency's (Baznas) Statistics Book shows that the collection of alms funds in 2016 only reached around IDR 5 trillion.

The gap between the alms potential and its realization is a challenge for amil alms to maximize this potential. Alms institutions and other stakeholders have made many efforts to increase alms collection such as maintaining the trust of muzakki in alms organizations (Handriana, 2016). The results of Handriana's research (2016) show that trust is a factor that plays an important role in shaping Muzakki's intention to keep in touch with alms management institutions and be able to encourage muzzaki compliance to fulfill his alms obligations. Another study by (Yuliafitri, 2016) explains that accountability is an important key to maintaining organizational stability. Most studies in the field of alms only focus on the internal perspective of the alms management organization. However, not many studies have previously examined the accountability of alms from muzakki as an external perspective (Yuliafitri, 2016; Rahayu, 2015; Erliana, Nelly; Adibah Suryaningsih, 2018). For this reason, this study tries to follow Fard's theory and modify it how to examine citizens (society/muzzaki) by looking at government accountability to determine the accountability role of alms management organizations from a muzakki perspective. In addition to the factors mentioned above, government regulations are assumed to influence motivation in paying alms at various levels of alms management organizations in Indonesia (Yasmin \& Haniffa, 2017; Mufidah, 2016). Mufidah's (2016) research results state that government regulations have an effect on the income of alms in alms institutions. The transformation of alms management from traditional management to professionals must be supported by modern management principles and the application of good corporate governance principles such as increasing transparency, accountability and professional principles of alms management organizations will be a value added for muzzaki to continue to maintain commitment and consistency in fulfilling their alms worship obligations (Rukmana, 2014; Ordanini, Miceli, \& Pizzetti, 2011; Adebayo et al., 2014). Departing from this empirical phenomenon, the purpose of this study is to analyze the effect of service quality on service satisfaction and muzzaki compliance in fulfilling the obligation to worship alms through alms management organizations.

\section{Theoretical framework and development of hypotheses}

\subsection{Good Corporate Government in the concept of Alms Service Quality}

As a concept, GCG apparently does not have a single definition. The Cadburry Committee, for example, in 1992 - through what is known as the Cadburry Report - issued its own definition of GCG. According to the Cadburry Committee, GCG is a principle that directs and controls the company in order to achieve a balance between the strength and authority of the company in providing accountability to shareholders in particular, and stakeholders in general (Mudashiru, Yusuf, Bakare, \& Ishmael, 2014). Of course this is intended to regulate the authority of directors, managers, shareholders, and other parties related to the development of the company in a particular environment. A number of countries also have their own definitions of GCG. Some countries define it with a somewhat similar understanding even though there are slight differences in terms. Developed countries group (OECD), for example defines GCG as ways of organizational management to be accountable to its shareholders (Uar, 2016; Mudashiru et al., 2014). Decision makers in the organization must be accountable, and the decision is able to provide added value for other shareholders. Therefore, the main focus here is related to the decision making process of the company which contains the values of transparency, responsibility, accountability, and of course fairness. Meanwhile, ADB (Asian Development Bank) explained that GCG contains 4 (four) main values, namely: Accountability, Transparency, Predictability and Participation (Uar, 2016). Another understanding came from the Finance Committee on Corporate Governance Malaysia. According to the agency, GCG is a process and structure used to direct and manage business and company affairs in the direction of increasing business growth and corporate accountability. The final goal is to increase the value of shares in the long term but still pay attention to the various interests of other stakeholders. As in the context of Good Corporate Governance (GCG) it is often also called "governance," or organizational governance, although in terms of the termonology it is still confused with management (Abdullah, 2018; Muhamad Ali, 2018). For this reason, studies are still needed to find the right terms in the correct Indonesian language. From the above definition it can be concluded that GCG is:

1) a structure that regulates the pattern of harmonious relationships about the roles of the board of commissioners, directors, shareholders and other stakeholders.

2) a system of checking and balancing authority over company control that can limit the emergence of two opportunities: mismanagement and misuse of organizational assets. 
3) a transparent process for determining company goals, achievements, and measurement of performance (Riswanto, Hurriyati, Wibowo, \& Gaffar, 2019b, 2019a).

According to SOE Ministry Regulation PER-01/MBU/2011 there are 5 (five) Good Corporate Government principles applied in its implementation, namely;

1) Transparency

To maintain objectivity in conducting business, companies must provide material and relevant information in a way that is easily accessible and understood by stakeholders.

2) Accountability

The company must be able to account transparently and fairly. For this reason, the company must be managed properly and measurably and in accordance with the interests of the company while taking into account the interests of shareholders and other stakeholders.

3) Responsibility

The company must comply with the rules and regulations as well as carry out responsibilities to the community and the environment so that business continuity can be maintained in the long term and be recognized as a good corporate citizen.

4) Independent (Independency)

To expedite the implementation of GCG principles, companies must be managed independently so that each organ of the company does not dominate each other and cannot be intervened by other parties.

5) Fairness and Fairness

In carrying out its activities, the company must always pay attention to the interests of shareholders and other stakeholders based on the principle of fairness and equality.

Based on the results of several previous studies on the use of Good Corporate Government variables (corporate governance) more associated with the concept of service quality and service satisfaction (Mudashiru et al., 2014; Sulistyowatie, 2018). That is, there is the same paradigm of thought to measure service quality with service satisfaction (Hanousek \& Palda, 2004). However, in several studies also mentioned that GCG has no significant effect on compliance but has a significant effect on service quality (Yuskar \& Amelia, 2014; Uar, 2016; Setiyawati \& Doktoralina, 2019). The concept of GCG in the context of research on muzzaki behavior produces findings that illustrate the significance of a positive relationship to increasing muzzaki compliance in fulfilling alms obligations. That is, good governance of alms service administration will be able to encourage the level of muzzaki compliance in paying alms. But the premise has not yet been found that connects the significant impact between service satisfaction with compliance, and vice versa in the concept of alms service performance. Customer service is related to service quality (Chen, 2010; Hafizah \& Mansor, 2013). Carrillat (2011) argues that service quality can be defined as the extent of the difference between the reality and the expectations of customers or the service they receive. Heizer and Render (2006) suggest the determinants of service quality, namely reliability, responsiveness, competence, access, courtesy, communication, credibility, security, understanding and tangibles. From the two concepts above, it can be concluded that it is said that service quality is the totality of forms and characteristics of products that can meet consumer expectations resulting in customer satisfaction (Hafizah \& Mansor, 2013; Darmawanto, 2015; Jermsittiparsert et al., 2019).

$\mathbf{H}_{1}$ : There is a relationship between the quality of alms services and the satisfaction of alms services.

\subsection{Compliance Paying Alms}

Alms is derived from an Arabic word meaning "cleanse" and "grow" (Ahmed \& Salleh, 2016). Individual behavior when paying Alms is part of open behavior. The determining factor for this behavior is the amount of individual intention whether or not to impose a certain behavior (Ajzen, 1991). Ajzen (1991) argues that intention can be used to predict the strength of an individual's willingness to perform a behavior and a number of plans and efforts to do so. Ajzen (1991) explains that in addition to attitudes, subjective norms and service quality, there is a fourth factor called behavioral control that a person feels is associated with a particular behavior. Therefore, according to Ajzen (1991) one's intention or behavior can be predicted through 3 (three) main determinants namely; attitudes toward certain behaviors, the influence of subjective norms and service quality. This theory is referred to as behavior planning theory (Ajzen, 1991). Therefore, it can be said that muzzaki's intention to pay his alms obligation is largely influenced by muzzaki's attitude towards the attributes inherent in the quality of alms services provided by alms management organizations, the influence of others closest to him, and also by his perception of behavioral control between the two. which can encourage intentions or hinder compliance in paying alms (Mukhlis \& Beik, 2013; Tajuddin et al., 2014; Farrell, Souchon, \& Geoffrey, 2001). From the description regarding this behavior theory, this study tries to analyze the effect of the quality of alms services on muzzaki compliance in paying alms which is carried out through alms management organizations.

$\mathbf{H}_{2}$ : There is a relationship between the quality of service and adherence to paying alms. 


\subsection{Alms Service Satisfaction}

Quality of service and customer satisfaction are basically different concepts; quality is seen as an attitude of purpose, while satisfaction is related to certain transactions (Gruber \& Gruber, 2010)). Llosa et al. (2011); and Farrel et al. (2001) relate perceived quality as an antecedent to satisfaction, while other authors such as Parasutaman et al. (1988) and Bitner (1990) view customer satisfaction as an antecedent to service quality. The majority of recent publications, among others, according to Yavas et al (2004), Carrillat et al (2007), Zeithaml et al (2008) believe that service quality is an antecedent to customer satisfaction and has a positive impact on their satisfaction. Parasuraman, Zeithmal and Berry (1994) found that one of the basic determinants of customer satisfaction is service quality. Spreng et al. (1996) also support previous findings and find a significant relationship between service quality and satisfaction. If previous theories succeed in proving the relationship and influence between service quality and satisfaction, it is not the case with the relationship between compliance with service satisfaction (Parasuraman et, 1988; Carrillat et, 2011; Bidin, 2009; Taylor, 2015). From the results of research in the field of taxation many have mentioned that the compliance of the tax authorities in paying taxes is much influenced by the satisfaction of the tax authorities in the process of tax services (Yuliani, 2016; Sarunan, 2015). Becker (1968) states that punishment can make individuals obedient because individuals consider economic benefits when doing negative things. Becker's (1968) economic motivated crime model is the basis of Allingham and Sandmo's (1972) research in modeling individual tax compliance decision making. However, the theoretical model is considered too simple to analyze taxpayer decisions to report the actual amount of income received (Cahyonowati, 2018; Suharto, 2011). That is, there is still a gap (theorycal gap) on the variable of compliance with satisfaction modeled in the tax concept. Whereas Bidin et al. (2009) found that muzzaki's compliance in paying alms was more influenced by ethical factors and the amount of income received by muzzaki. From the review of the two research cases in the two units of analysis that have different characteristics it can be seen clearly that there is a gap (research gap) that has not been tested, namely the direct relationship between compliance with service satisfaction.

H3: There is a relationship between the compliance of paying alms and alms service satisfaction.

\section{Research Methodology}

\subsection{Types of research}

This type of research is quantitative descriptive statistical research by testing the hypothesis that has been proposed that is testing the effect of independent variables on the dependent variable.

\subsection{Research Model}

The research model that will be used to test the relationship between research variables is as follows:

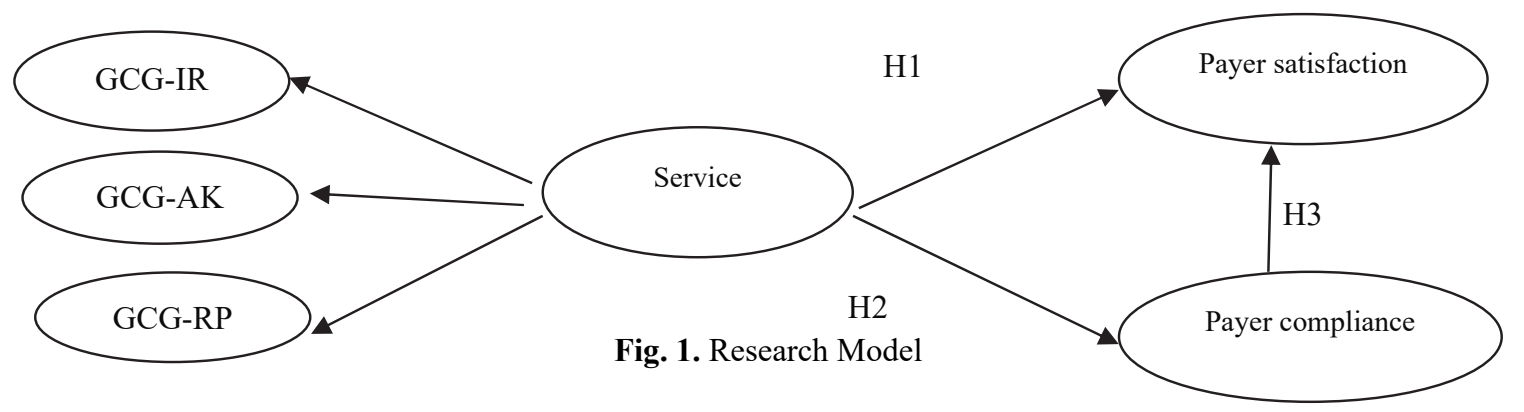

\subsection{Research Samples}

The sampling technique used in this study is simple random sampling by distributing questionnaires to muzzaki who are permanent employees in an academic environment. The questionnaire was distributed online using the Google Form application with a total of 132 respondents.

\subsection{Data analysis technique}

The data analysis technique used in this study is the test measurement of the path analysis research model with the Semantic Equation Model (SEM) technique with the aim of making the construct paradigm of thinking more logical in measuring the relationship between the variables studied. The results of the analysis to be obtained from this data analysis technique are the construct of the analysis model, the analysis of influence and relationships, and testing of research hypotheses. The research data was processed using AMOS 22 software.

\section{Results And Discussion}

\subsection{Descriptive Analysis}

Descriptive analysis includes data related to respondents' perceptions regarding research variables, in this case the variables in this study are the quality of alms services, satisfaction of alms services and compliance to pay alms. 
Table 1

Characteristics of Respondents

\begin{tabular}{|c|c|c|c|}
\hline Characteristics & Classification & Freq. & $\%$ \\
\hline \multirow[t]{2}{*}{ Gender } & Male & 66 & 50.0 \\
\hline & Female & 66 & 50.0 \\
\hline \multirow{3}{*}{ Age } & $20-30$ & 29 & 22.0 \\
\hline & $31-45$ & 63 & 47.7 \\
\hline & $>46$ & 40 & 30.3 \\
\hline \multirow{3}{*}{ Education } & High school & 3 & 2.3 \\
\hline & Undergraduate & 41 & 31.1 \\
\hline & Master & 88 & 66.7 \\
\hline \multirow{5}{*}{ Profession } & Employees & 42 & 31.8 \\
\hline & Civil servants & 20 & 15.2 \\
\hline & Professional & 30 & 22.7 \\
\hline & Entrepreneur & 8 & 6.1 \\
\hline & Etc. & 32 & 24.2 \\
\hline \multirow{4}{*}{ Earnings Per Month } & Above Rp. $10,000,000$ & 13 & 9.8 \\
\hline & Less than Rp. 2,000,000 & 16 & 12.1 \\
\hline & Rp. $2,000,000$ - Rp. $5,000,000$ & 58 & 43.9 \\
\hline & Rp. $5,000,000-$ Rp. $10,000,000$ & 45 & 34.1 \\
\hline
\end{tabular}

Table 1 illustrates the characteristics of respondents. From 132 respondents, each gender includes 66 people (50.0\%). By age, of the 132 respondents the most respondents were aged between 31 years and 45 years, as many as 63 people (47.7\%). Based on their level of education. Of the 132 respondents, 88 respondents hold master degrees of science (66.7\%). In terms of occupation, 42 respondents worked as private employees. In terms of income per month, 58 respondents earned between Rp. 2,000,000 to Rp. 5,000,000 (34.1\%).

\subsection{Description of Respondents' Perceptions}

The data description of respondents' responses can be used to enrich the discussion, through the description of respondents' response data it can be seen how the condition of each indicator variable being studied. To make it easier to interpret the variables being studied, categorization of the respondent's score is done. The principle of categorization is based on Sugiyono (2015) on the weight of the score by finding the interval of each category based on the highest and lowest number of scales, to produce the classification as in Table 2.

Table 2

Score Interpretation Categories

\begin{tabular}{lll}
\hline No & Interval & Category \\
\hline $\mathbf{1}$ & $1.0-2.2$ & Very Poor/Very Low \\
$\mathbf{2}$ & $2.3-3.4$ & Not Good/Low \\
$\mathbf{3}$ & $3.5-4.6$ & Enough \\
$\mathbf{4}$ & $4.7-5.8$ & Good/High \\
$\mathbf{5}$ & $5.9-7.0$ & Very Good/Very High \\
\hline
\end{tabular}

Table 3

Respondents' Responses to the Quality of Alms Services (SQ)

\begin{tabular}{|c|c|c|c|c|c|c|c|c|c|c|}
\hline \multirow{2}{*}{ No } & \multirow{2}{*}{ Statement } & \multicolumn{7}{|c|}{ Alternative Answers } & \multirow{2}{*}{ amount } & \multirow{2}{*}{ Average } \\
\hline & & 1 & 2 & 3 & 4 & 5 & 6 & 7 & & \\
\hline 1 & SQ1 & 14 & 12 & 18 & 36 & 34 & 7 & 11 & 132 & 4.0 \\
\hline 2 & SQ2 & 14 & 11 & 20 & 39 & 24 & 15 & 9 & 132 & 4.0 \\
\hline 3 & SQ3 & 21 & 17 & 21 & 27 & 20 & 17 & 9 & 132 & 3.7 \\
\hline 4 & SQ4 & 11 & 17 & 17 & 30 & 28 & 15 & 14 & 132 & 4.1 \\
\hline 5 & SQ5 & 11 & 19 & 12 & 28 & 36 & 13 & 13 & 132 & 4.1 \\
\hline \multicolumn{9}{|c|}{ GCG - Transparency } & \multicolumn{2}{|c|}{4.0} \\
\hline 6 & SQ1 & 11 & 9 & 19 & 32 & 31 & 17 & 13 & 132 & 4.3 \\
\hline 7 & SQ2 & 10 & 15 & 13 & 27 & 32 & 24 & 11 & 132 & 4.3 \\
\hline 8 & SQ3 & 7 & 10 & 18 & 29 & 34 & 18 & 16 & 132 & 4.4 \\
\hline 9 & SQ4 & 10 & 9 & 20 & 28 & 32 & 19 & 14 & 132 & 4.3 \\
\hline 10 & SQ5 & 8 & 8 & 14 & 27 & 37 & 25 & 13 & 132 & 4.5 \\
\hline \multicolumn{9}{|c|}{ GCG - Accountability } & \multicolumn{2}{|c|}{4.4} \\
\hline 11 & SQ1 & 7 & 9 & 20 & 32 & 23 & 30 & 11 & 132 & 4.4 \\
\hline 12 & SQ2 & 7 & 5 & 18 & 32 & 36 & 19 & 15 & 132 & 4.5 \\
\hline 13 & SQ3 & 7 & 5 & 15 & 35 & 29 & 28 & 13 & 132 & 4.6 \\
\hline 14 & SQ4 & 9 & 7 & 16 & 26 & 34 & 23 & 17 & 132 & 4.6 \\
\hline 15 & SQ5 & 8 & 9 & 18 & 31 & 27 & 27 & 12 & 132 & 4.4 \\
\hline \multirow{2}{*}{\multicolumn{2}{|c|}{$\begin{array}{l}\text { GCG - Responsibility } \\
\text { Quality of Service (X) }\end{array}$}} & & & & & & & & \multirow{2}{*}{\multicolumn{2}{|c|}{$\begin{array}{l}4.5 \\
4.3\end{array}$}} \\
\hline & & & & & & & & & & \\
\hline
\end{tabular}


From the calculations in the table shows the average score obtained 3 . Thus, this showed that the alms service quality is in the range of good or high categories (4.6-5.8).

Table 4

Respondents' Responses Regarding Service Satisfaction (SS)

\begin{tabular}{|c|c|c|c|c|c|c|c|c|c|c|}
\hline \multirow{2}{*}{ No } & \multirow{2}{*}{ Statement } & \multicolumn{7}{|c|}{ Alternative Answers } & \multirow[b]{2}{*}{ Amount } & \multirow{2}{*}{ Average } \\
\hline & & 1 & 2 & 3 & 4 & 5 & 6 & 7 & & \\
\hline 1 & SS1 & 10 & 7 & 24 & 30 & 30 & 18 & 13 & 132 & 4.3 \\
\hline 2 & $\mathrm{SS} 2$ & 9 & 9 & 16 & 30 & 34 & 22 & 12 & 132 & 4.4 \\
\hline 3 & $\mathrm{~S} 3$ & 10 & 9 & 15 & 35 & 29 & 20 & 14 & 132 & 4.4 \\
\hline \multicolumn{9}{|c|}{ Service Satisfaction $\left(\mathrm{Y}_{1}\right)$} & \multicolumn{2}{|c|}{4.3} \\
\hline
\end{tabular}

Respondents response regarding service satisfaction, from the calculations in table 4 shows the average score obtained 4.3 . Thus, service satisfaction is in the range of either high or high categories (4.6 - 5.8).

Table 5

Respondents Response Regarding Compliance Paying Alms (PC)

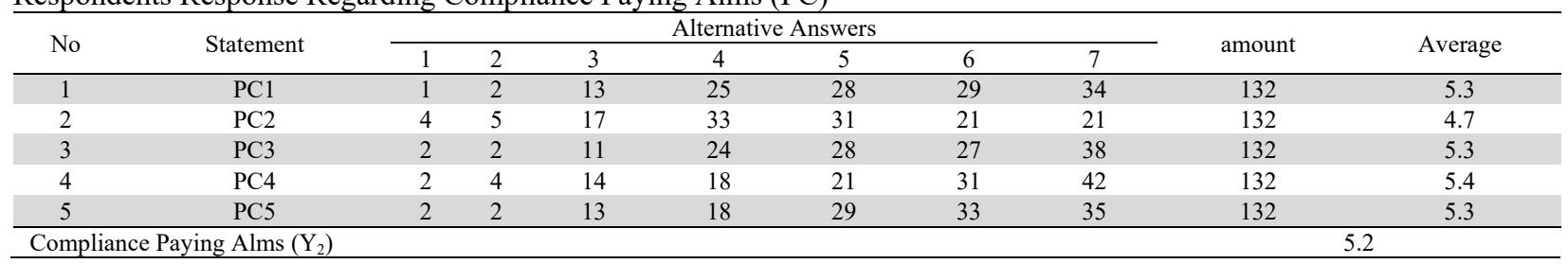

Regarding compliance paying alms, from the calculations in Table 5 shows the average score obtained 5.2. Thus, compliance paying alms is in the range of good or high categories (4.6-5.8).

\subsection{Structural Equation Model Analysis (SEM)}

The phase in SEM analysis technique is the measurement model stage. The measurement model is used to measure the dimensions that make up a factor. Estimation technique used in SEM calculation is to use maximum likelihood. But before forming a full SEM model, testing of the factors that make up each variable will first be done. Testing will be done by looking at the results of standardized regression weight in the AMOS output table. If there is an estimate value of the indicators that have an estimated value $<0.5$ then the indicator cannot describe the construct.

Table 6

Exogenous Construction Measurement Model

\begin{tabular}{|c|c|c|c|c|c|c|}
\hline Latent Variable & Manifest Variable & $\lambda$ & $\lambda^{2}$ & $\mathrm{e}$ & $\mathrm{CR}$ & $\mathrm{VE}$ \\
\hline \multirow{3}{*}{ Quality of Alms Service (X) } & $\mathrm{X} 1.1$ & 0.87 & 0.757 & 0.75 & \multirow{11}{*}{9.77} & \multirow{11}{*}{0.500} \\
\hline & $\mathrm{X} 1.2$ & 0.97 & 0.941 & 0.94 & & \\
\hline & $\mathrm{X} 1.3$ & 0.94 & 0.884 & 0.89 & & \\
\hline \multirow{3}{*}{ Service Satisfaction (Y1) } & Y1.1 & 0.90 & 0.810 & 0.82 & & \\
\hline & Y1.2 & 0.95 & 0.903 & 0.90 & & \\
\hline & Y1.3 & 0.95 & 0.903 & 0.90 & & \\
\hline \multirow{5}{*}{ Compliance Paying Alms (Y2) } & Y2.1 & 0.88 & 0.774 & 0.77 & & \\
\hline & Y 2.2 & 0.77 & 0.593 & 0.59 & & \\
\hline & Y2.3 & 0.85 & 0.723 & 0.73 & & \\
\hline & Y2.4 & 0.85 & 0.723 & 0.72 & & \\
\hline & Y2.5 & 0.87 & 0.757 & 0.76 & & \\
\hline
\end{tabular}

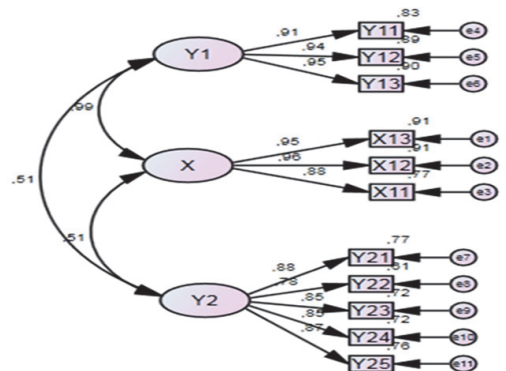

Fig. 2. Exogenous Constructive Measurement Model

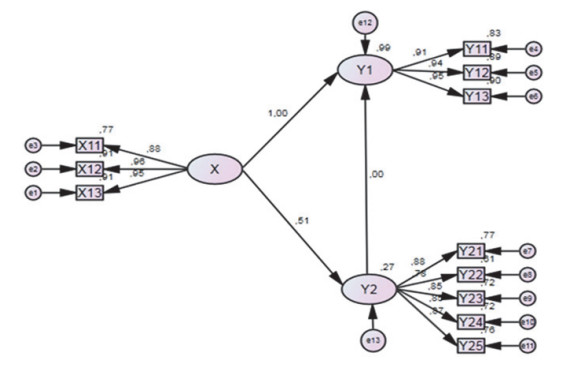

Fig. 3. Path Diagram of Structural Model SEM

Table 6 shows that the loading factor $(\lambda)$ value for each manifest variable is greater than 0.5 . This means that each manifest variable is declared valid in forming an exogenous construct. Then the value of CR (construct reliability) must be above 0.7 
and VE (variance extracted) must be above 0.5 already fulfilled so it can be concluded that all exogenous constructs have good construct validity and reliability. The results of SEM structural modeling analysis using AMOS software can be seen in Fig. 3. Thus, the structural equation can be described below:

1) $\mathrm{Y} 1=0.995 \times \mathrm{X}-0.002 \times \mathrm{Y} 2$, Errorvar. $=0.99, \mathrm{R}^{2}=0.989$

2) $\mathrm{Y} 2=-0.515 \times \mathrm{X}$, Errorvar. $=0.27, \mathrm{R}^{2}=0.265$

Information: $\mathrm{X}=$ Quality of Alms Service; $\mathrm{Y}_{1}=$ Service Satisfaction; $\mathrm{Y}_{2}=$ Compliance Paying Alms

From the first equation, it can be explained that the direction of the relationship of Alms Service Quality (X) with Service Satisfaction $\left(\mathrm{Y}_{1}\right)$ is positive. The total effect of the first equation is equal to $98.9 \%$. While in the second equation the relationship between Alms Service Quality $(\mathrm{X})$ and Alms Paying Compliance $\left(\mathrm{Y}_{2}\right)$ is positive and the relationship between Service Satisfaction $\left(\mathrm{Y}_{1}\right)$ and Alms Paying Compliance $\left(\mathrm{Y}_{2}\right)$ is negative with a total effect of $26.5 \%$. Meanwhile, the Goodness of fit criteria of the structural equation model of the research model can be presented in Table 7 .

Table 7

\begin{tabular}{|c|c|c|c|c|}
\hline No. & Goodness of Fit Index & Cut-off Value & Results & Conclusion \\
\hline 1 & Chi-Square & Expected Small (under table values) & $2.659<32.072$ & Good Fit \\
\hline 2 & Significant Probability & $\geq 0.05$ & 0.000 & Bad Fit \\
\hline 3 & RMSEA & $\leq 0.08$ & 0.113 & Bad Fit \\
\hline 4 & GFI & $\geq 0.90$ & 0.882 & Marginal Fit \\
\hline 5 & AGFI & $\geq 0.90$ & 0.810 & Marginal Fit \\
\hline 6 & RFI & $\geq 0.90$ & 0.919 & Good Fit \\
\hline 6 & NFI & $\geq 0.95$ & 0.938 & Good Fit \\
\hline 7 & CFI & $\geq 0.94$ & 0.960 & Good Fit \\
\hline
\end{tabular}

Table 7 shows that even though the Significant Probability and RMSEA values do not meet the required cut of value requirements, the research model has a chi-square value of 2.659 or below the table value of 32.072, GFI and AGFI that still meet the requirements of the acceptance of the research model. That is, the research model is still not considered perfect but can still be accepted as a research model that can be measured.

\subsection{Hypothesis testing}

The next goal in the analysis of structural models is to estimate the parameters of influence between variables, which at the same time will also prove the research hypothesis. The following is a summary of the estimated parameters from the SEM analysis that has been carried out as presented in Table 8 .

Table 8

Hypothesis Testing

\begin{tabular}{|c|c|c|c|c|c|}
\hline \multicolumn{3}{|c|}{ Variable } & $\mathrm{t} \mathrm{-}_{\text {stat. }}$ & $t_{- \text {table }}$ & Information \\
\hline $\mathrm{X}$ & $\rightarrow$ & Y1 & 18.646 & 1.960 & Significant \\
\hline$X$ & $\rightarrow$ & Y2 & 6.078 & 1.960 & Significant \\
\hline Y1 & $\rightarrow$ & $\mathrm{Y} 2$ & 0.055 & -1.960 & Not Significant \\
\hline
\end{tabular}

Statistical results on testing the first hypothesis states that alms service quality affects service satisfaction and it shows the value of the standardized regression weight coefficient between alms service quality variable $(\mathrm{X})$ with service satisfaction variable $\left(\mathrm{Y}_{1}\right)$ is 0.995 (positive) and has a $\mathrm{t}$-stat. of 18.664 or greater than 1 . This means that the alms service quality variable $(\mathrm{X})$ is significant towards the service satisfaction variable $\left(\mathrm{Y}_{1}\right)$. Thus, hypothesis $1\left(\mathrm{H}_{1}\right)$ was accepted. The coefficient of 0.995 indicates that if the alms service quality $(\mathrm{X})$ is increased by one unit, the service satisfaction $\left(\mathrm{Y}_{1}\right)$ will increase by 0.995 units. It means that higher quality of alms services ideally will be followed by increasingly increasing alms service satisfaction. Testing on second hypothesis stating that the quality of alms services affects the compliance of paying alms shows the standardized regression weight coefficient between alms service quality $(\mathrm{X})$ and alms paying compliance variable $\left(\mathrm{Y}_{2}\right)$ is 0.515 (positive) and has a t-stat. of 6.078 or greater than 1.96. This means that the alms service quality (x) variable is significant towards the alms compliance variable $\left(\mathrm{Y}_{2}\right)$. Thus, hypothesis $2\left(\mathrm{H}_{2}\right)$ was accepted. The coefficient of 0.636 indicates that if the alms service quality $(\mathrm{x})$ is increased by one unit, the compliance of paying alms $\left(\mathrm{y}_{2}\right)$ will increase by 0.515 units. This means that higher quality of alms services will be followed by increasing alms payment compliance. Testing on third hypothesis stating that compliance paying alms affects service satisfaction and it shows that the standardized regression weight coefficient between service satisfaction $\left(\mathrm{y}_{1}\right)$ and alms paying compliance variable $\left(\mathrm{y}_{2}\right)$ is 0.002 (negative) and has a $t$ value of 0.055 or smaller than 1.96. This means that the alms compliance variable $\left(\mathrm{y}_{2}\right)$ is not significant to the service satisfaction variable $\left(\mathrm{y}_{1}\right)$. Thus, hypothesis 3 is rejected. Next is testing on simultaneous effect stating that alms service quality and compliance paying alms has a simultaneous effect (test $\mathrm{f}$ ) on service satisfaction. To test the hypothesis simultaneously $\mathrm{F}$ test is used. The condition is if the value $F$-stat. greater than $F$-table, it means that there is a significant influence between alms service 
quality $(\mathrm{x})$ and alms paying compliance $\left(\mathrm{y}_{2}\right)$ simultaneously affecting service satisfaction $\left(\mathrm{Y}_{1}\right)$. The following is the calculation result based on the formula above.

Table 9

Hypothesis Test of Simultaneous Effect (F-Test)

\begin{tabular}{|c|c|c|c|c|c|}
\hline & Variable & & $\mathrm{F}_{\text {-stat. }}$ & F-Table & Information \\
\hline $\begin{array}{l}\mathrm{X} \\
\mathrm{Y}_{2}\end{array}$ & $\rightarrow$ & $\mathrm{Y}_{1}$ & 46.510 & 3.066 & Significant \\
\hline
\end{tabular}

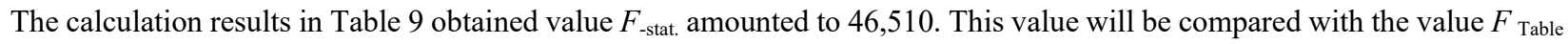
with a sample size of 132 obtained $F_{\text {-table }}$ amounted to 3.066 . The results showed that $F_{\text {-stat. }}>F_{\text {-table. It means that simultane- }}$ ously alms service quality and alms paying compliance affect service satisfaction.

\section{Conclusions and Discussion}

The results of statistical analysis using SEM path analysis concluded that alms service quality that applies the gcg principles does have a significant relationship and influence with service satisfaction and muzzaki compliance in fulfilling their alms obligations. That is, if the quality of alms services is based on the principles of good and quality GCG, then this will be able to encourage increased alms service satisfaction for muzzaki while also being able to increase muzzaki compliance in fulfilling their alms worship obligations $\left(\mathrm{H}_{1}\right.$ and $\mathrm{H}_{2}$, were accepted). However, what needs to be underlined in this study is the same findings as the findings of previous studies which state that adherence to paying alms has no significant effect and has a very weak variable relationship. With service satisfaction, indicated by $R^{2}=26.5 \%$. This also supported by the results that $\mathrm{H}_{3}$ was rejected. This means that the muzzaki compliance variable in fulfilling its alms obligations is not influenced or influences tax service satisfaction. In the structural model SEM still requires other mediator variables or other dimensions and indicators which may not be included in this study. The new logical thinking paradigm to the concept of applying GCG principles in service quality as a reference to improve compliance and satisfaction of alms services empirically is indeed very appropriate to be used as a basis in measuring the performance of alms management organizations in Indonesia. However, on the other hand that needs to be an important concern is avoiding the paradigm of thinking that connects paying alms compliance with muzzaki service satisfaction. That is, the compliance of muzzaki in fulfilling their alms worship obligations is not caused or caused by the satisfaction of alms services by alms management organizations but rather is caused by the quality of alms services provided to muzzaki.

\section{Implications and Limitations}

Practical implications that can be obtained from the results of this study are of course the existence of a strong theory to build muzzaki trust in alms management organizations in collecting and distributing alms funds in accordance with muzzaki expectations. The quality of alms services, which is based on GCG principles, is apparently able to have positive implications for service satisfaction and muzzaki compliance in fulfilling their alms worship obligations voluntarily. The better and better quality of alms services provided by alms management organizations to muzzaki, the higher the level of service satisfaction and compliance of muzzaki to fulfill their alms obligations without coercion. The limitation of this study is the lack of mediating variables that connect the compliance variable with service satisfaction, so that it appears in the research model measured in the third hypothesis $\left(\mathrm{H}_{3}\right)$ become insignificant. That is, it takes a dimension and measurement with different variables that will be more precisely used to measure the relationship between the variable compliance with service satisfaction.

\section{Acknowledgement}

The authors thank for the support of all parties who were very helpful in the research and publication of this article. The authors would like to express deepest thanks to the team of Nanang Fattah, Kusnendi, and Mokh. Adib Sultan, who are graduate school lecturers from the Management Science Doctoral Study Program, Universitas Pendidikan Indonesia. The authors sincerely thank the LPDP (Lembaga Pengelola Dana Pendidikan / Education Fund Management Institution) of the Ministry of Finance of the Republic of Indonesia for financial support of this research.

\section{References}

Abdullah, M. (2018). Waqf, Sustainable Development Goals (SDGs) and maqasid al-shariah. International Journal of Social Economics, 45(1), 158-172.

Adebayo, M., Ibrahim, A. B., Yusuf, B., \& Omah, I. (2014). Good corporate governance and organizational performance: An empirical analysis. International Journal of Humanities and Social Science, 4(7), 1.

Ahmed, H., \& Salleh, A. M. H. A. P. M. (2016). Inclusive Islamic financial planning: a conceptual framework. International Journal of Islamic and Middle Eastern Finance and Management, 9(2), 170-189.

Ajzen, I. (1991). The theory of planned behavior. Organizational behavior and human decision processes, 50(2), $179-211$. 
Ali, K. M., Ali, Z. M., Ahmad, S., \& Zain, M. N. M. (2017). Konsep dan Pihak yang Bertanggungjawab dalam Pengurusan Zakat. Islamiyyat, 39(1), 3-9.

Bidin, Z., Idris, K. M., \& Shamsudin, F. M. (2009). Predicting compliance intention on zakah on employment income in Malaysia: An application of reasoned action theory. Jurnal Pengurusan (UKM Journal of Management), 28.

Cahyonowati, N., \& Darsono, D. (2018). Perkembangan model penelitian kepatuhan pajak. Simak, 16(01), 01-11.

Chen, C. W. (2010). Impact of quality antecedents on taxpayer satisfaction with online tax-filing systems-An empirical study. Information \& Management, 47(5-6), 308-315.

Cronin Jr, J. J., \& Taylor, S. A. (1992). Measuring service quality: a reexamination and extension. Journal of marketing, 56(3), 55-68.

Darmawanto, A. T. (2015). Analisis Kualitas Pelayanan Pajak Terhadap Kepuasan Wajib Pajak Badan Di Kantor Pelayanan Pajak Madya Malang. Jurnal Ilmu Ekonomi dan Pembangunan, 15(1).

Erliana, N., \& ABIDAH SURYANINGSIH, S. R. I. (2018). Pengaruh persepsi layanan jemput zakat terhadap kepuasan muzakki di lembaga amil zakat yatim mandiri cabang jombang. Jurnal Ekonomi Islam, 1(2).

Farrell, A. M., Souchon, A. L., \& Durden, G. R. (2001). Service encounter conceptualisation: employees' service behaviours and customers' service quality perceptions. Journal of Marketing Management, 17(5-6), 577-593.

Gruber, T., Fuß, S., Voss, R., \& Gläser-Zikuda, M. (2010). Examining student satisfaction with higher education services: Using a new measurement tool. International Journal of Public Sector Management, 23(2), 105-123.

Handriana, T. (2016). Analysis of donoree s trust and relationship commitment in lembaga amil zakat in Indonesia. Journal of Economics, Business, and Accountancy Ventura, 19(1), 59-68.

Hanousek, J., \& Palda, F. (2004). Quality of government services and the civic duty to pay taxes in the Czech and Slovak Republics, and other transition countries. Kyklos, 57(2), 237-252.

Jermsittiparsert, K., Siam, M., Issa, M., Ahmed, U., \& Pahi, M. (2019). Do consumers expect companies to be socially responsible? The impact of corporate social responsibility on buying behavior. Uncertain Supply Chain Management, 7(4), 741-752.

Johari, F., Ali, A. F. M., AbAziz, M. R., \& Ahmad, N. (2014). The importance of zakat distribution and urban-rural poverty incidence among Muallaf (new convert). Asian Social Science, 10(21), 35.

Llosa, S., Orsingher, C., Carrillat, F. A., Jaramillo, F., \& Mulki, J. P. (2007). The validity of the SERVQUAL and SERVPERF scales. International Journal of Service Industry Management.

Mansor, N. H., \& Ilias, A. (2013). Goods and services tax (GST): A new tax reform in Malaysia. International Journal of Economics Business and Management Studies, 2(1), 12-19.

Mufidah, M. (2016). Sistem Hirarki Kelembagaan Badan Pengelola Zakat di Indonesia (Tinjauan terhadap Pelaksanaan Undang-undang No. 23 Tahun 2011). Jurnal Cita Hukum, 4(2).

Mukhlis, A., \& Beik, I. S. (2013). Analisis faktor-faktor yang memengaruhi tingkat kepatuhan membayar zakat: Studi kasus Kabupaten Bogor. Al-Muzara'ah, 1(1), 83-106.

Ordanini, A., Miceli, L., Pizzetti, M., \& Parasuraman, A. (2011). Crowd-funding: transforming customers into investors through innovative service platforms. Journal of Service Management, 22(4), 443-470.

Parasuraman, A., Zeithaml, V. A., \& Berry, L. L. (1988). Servqual: A multiple-item scale for measuring consumer perc. Journal of retailing, 64(1), 12.

Rahayu, R. (2015). Faktor-Faktor Determinan Motivasi Muzzaki Membayar Alms ke Lembaga Zakat.

Riswanto, A., Hurriyati, R., Wibowo, L. A., \& Gaffar, V. (2019). Empirical assessment of the role of product innovation in dynamic marketing capabilities and company performance. Quality-Access to Success, 20(173).

Riswanto, A., Hurriyati, R., Wibowo, L. A., \& Gaffar, V. (2019). Effect of market orientation on business performance in MSMEs as mediating by Dinamic marketing capabilities. Calitatea, 20(172), 78-83.

Rukmana, Y. (2014). Kedudukan Arah Transformasi Lembaga Amil Zakat (LAZ). Iqtishodia, 23.

Sarunan, W. K. (2016). Pengaruh Modernisasi Sistem Administrasif Perpajakan Terhadap Kepatuhan Wajib Pajak Orang Pribadi Dan Wajib Pajak Badan Pada Kantor Pelayanan Pajak Pratama Manado. Jurnal EMBA: Jurnal Riset Ekonomi, Manajemen, Bisnis dan Akuntansi, 3(4).

Setiyawati, H., \& Doktoralina, C. (2019). The importance of quality accounting information management in regional governments in Indonesia. Management Science Letters, 9(12), 2083-2092.

Suharto, S. (2011). Pengaruh kepuasan wajib pajak terhadap kepatuhan wajib pajak. Derivatif Jurnal Manajemen, 5(1).

Sulistyowatie, S. L., \& Pahlevi, R. W. (2018). Penerapan good corporate governance, whistleblowing system dan risiko sanksi pajak terhadap kepatuhan wajib pajak di kabupaten sleman. Riset Akuntansi dan Keuangan Indonesia, 3(2), $152-160$.

Tajuddin, T. S. B., Aman, Z. B., \& Ismail, S. B. (2014). Management accounting practices in non-profit religious organization: a case study in lembaga zakat selangor (LZS). E-Proceedings (May), 978-983.

Uar, A. (2016). Pengaruh Pelaksanaan Prinsip-Prinsip Good Governance Terhadap Kinerja Pelayanan Publik Pada Badan Pertahanan Nasional (BPN) Kota Ambon. Otoritas: Jurnal Ilmu Pemerintahan, 6(1), 1-11.

Vicente-Ramos, W., Reymundo, K., Pari, L., Rudas, N., \& Rodriguez, P. (2020). The effect of good corporate governance on banking profitability. Management Science Letters, 10(9), 2045-2052.

Yasmin, S., \& Haniffa, R. (2017). Accountability and narrative disclosure by Muslim Charity Organisations in the UK. Journal of Islamic Accounting and Business Research, 8(1), 70-86.

Yuliafitri, I., \& Khoiriyah, A. N. (2016). Pengaruh Kepuasan Muzakki, Transparansi dan Akuntabilitas pada Lembaga Amil Zakat Terhadap Loyalitas Muzakki (Studi Persepsi Pada LAZ Rumah Zakat). Islamiconomic: Jurnal Ekonomi Islam, 7(2). 
Yuliani, N. L. (2016). Analisis determinan tingkat kepatuhan membayar pajak wajib pajak orang pribadi.

Yuskar, \& Amelia, R. (2014). Analisis kinerja kantor pelayanan penyuluhan dan konsultasi perpajakan terhadap kepatuhan wajib pajak (Studi Empiris di KP2KP Padangpanjang). Jurnal Riset Akuntansi Dan Bisnis 14, 31-51.

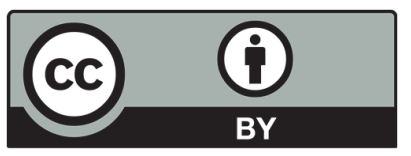

(C) 2020 by the authors; licensee Growing Science, Canada. This is an open access article distributed under the terms and conditions of the Creative Commons Attribution (CC-BY) license (http://creativecommons.org/licenses/by/4.0/). 